\title{
The Characteristics of Values of Sustainable and Universal Local Wisdom in Spatial Arrangement in Bali and Aceh Provinces
}

\author{
Dr. I Ketut Kasta Arya Wijaya,SH.M.Hum. \\ Dr. Ni Made Jaya Senastri,SH.MH. \\ Dr. Teuku Nazarudin,SH.M.Hum. \\ Dr. Sulaiman, SH.M.Hum. \\ Joint research between Warmadewa University, Denpasar, Bali with Malikusaleh University, Aceh
}

\begin{abstract}
This study examined and identified the characteristics of local wisdom values in the content material contained in the Regional Regulation of Bali province and Aceh Special region on Regional Spatial Plan, local wisdom values outlined in the RTRW Regulation are values that are believed by local communities in behaving within the community. This research will find a correlation of local wisdom values set forth in the RTRW Regulation with the level of Obedience in implementing existing rules. This study uses normative legal research normative legal research because this research will inventory the values of local wisdom contained in the content material. The results of the study can be described as follows that the values of local wisdom in Bali have characteristics when viewed from several aspects such as aspects of orientation, partisanship, respect for human rights, implementation of management and Good Governance found the value of local wisdom, among others: conservation or maintenance oriented, on aspects of partisanship of spatial arrangement in favor of the community or karama by protecting nature and the environment. From damage and pollution, on the aspect of human rights protection of spatial regulations has accommodated the value of wisdom that respects human rights, Tat Twam Asi. The Aceh RTRW Regulation has not accommodated the local wisdom of structuring the space of the residential area and providing protection for mukim management areas from development activities and exploitative projects damaging and threatening people's livelihoods and potentially causing disasters. This is because the legal political power owned by the Mukim community has not been able to influence policies related to spatial arrangements, even though many values of local wisdom can be used as guidelines in spatial arrangement in Aceh, related to respect, protection and fulfillment of rights to the community in providing welfare.
\end{abstract}

Keywords: Values of local wisdom, Characteristic, Legal politic.

DOI: $10.7176 / J L P G / 116-05$

Publication date: December $31^{\text {st }} 2021$

\section{Introduction}

\subsection{Background}

The recognition of local wisdom becomes a part of state life recognized by the constitution based on Article $18 \mathrm{~B}$ paragraph (2) of the 1945 NRI Constitution which specifies "The State recognizes and respects the unity of indigenous peoples and their traditional rights as long as they are alive and in accordance with the development of society in the principle of the Unitary State of the Republic of Indonesia stipulated in the law". Affirmed in the provisions of Article 28 I paragraph (1), which outlines that "The cultural identity and rights of traditional peoples are respected in harmony with the development of times and civilizations." This reflects therecognition of the existence of indigenous peoples in thecontrol and utilization of space.

In the law of spatial arrangement the State provides an opportunity for each region to bestow their own characteristics. By giving space to the area to bring out its characteristics then this is where the values of local wisdom will be accommodated in the spatial arrangement arrangement. Policy determination in the field of agrarian including spatial arrangement, guaranteed in the explanation of BAL (Basic Agrarian Lawa) which states that customary law is the basis of the establishment of agrarian law. ${ }^{\mathrm{i}}$

Local wisdom values are still used in managing the environment, natural resources and spatial planning where knowledge and technology that indigenous peoples use. Through a long process of interaction and adaptation to the environment and natural resources, indigenous peoples are able to develop ways to sustain life by creating value systems, lifestyles, institutional and legal systems that are in harmony with the conditions and availability of natural resources around the area they live in. ${ }^{\text {ii }}$

Regional regulations on the Bali Regional Spatial Plan by carrying the philosophy of Nangun sad kerthi, then the value oflocal wisdom in religious teachings becomes a guideline in the development of Bali. Similarly, in other areas that adhere to islamic religiousness, Tends accommodates the values of local wisdom from teachings relevant to keyakonan that are still relevant in the current context, such as acehnese people, Acehnese people in the past have created various traditional restrictions, traditional ceremonies and also various other traditions in fostering a harmonious environment. If observed the various cultural elements created it can 
reveal various messages that have the meaning of the need to maintain a harmonious relationship with the surrounding environment.

Among these messages there are those that are magically sacred, so they are not conveyed directly, but with restrictions full of symbolic meanings. Thus to interpret it requires a deep understanding of the socio-cultural background of acehnese people. In the Special Area of Aceh philosophical spatial "Mukim Indigenous Law Society in Aceh" is known as Tuha Peut and Tuha Lapan whose philosophy is territorial orientation. When connected with the background and embodiment of mukim "space", that the organization of mukim space originally coincided with the type of holy place / worship. The position or location of the Mosque is the temporary center of Gampong-Gampong around it, whose residents come to the Mosque to worship, is the area of service.

With customs and cultures that are identical to Islam, then in the context of Mukim and Mosque at once covered by the customs and culture of the community. Philosophical spatial mukim contains the compatibility of the relationship between man with God (Allah Swt) or hablumminAllah, man with humans or hablumminannas including relationships with the environment / universe, in Aceh term called the relationship Lhee Sagoe (Three Facets) In addition there are also provisions that are created but then changed because it is no longer in accordance with the times, for example Customs or habits that can cause mudharat for the people of Aceh. . ii $^{\text {ii }}$

From the background description above, researchers want to examine more in-depth about the characteristics of local wisdom values in indigenous balinese communities with aceh special region, then with the results of this study will be found karateristik local wisdom of each region as outlined in regional regulations regarding spatial arrangement. Furthermore, by examining the characteristics of each local wisdom will be able to find the concept of local wisdom values that are universal and applicable throughout Indonesian society.

\subsection{Problem}

Thus from the background description above can be formulated the following problems: How is the characteristic of values of local wisdom that are sustainable, equitable and useful and legal in the Regional Regulation of Spatial and Regional Plans in Bali Province and Aceh Special Region?

\subsection{Research Methods}

This research uses normative legal research,. So that the culture or culture of law is one part of the legal system can be a reference in the formation of legislation, especially in the State of Law. Problem approach uses a statutory approach, a concept approach, an analytic approach, a comparison approach.

\subsection{Results and Discussions}

\subsubsection{Local Wisdom in Spatial Arrangement in Bali}

Local wisdom consists of two words: wisdom and local wisdom. In general, the meaning of local wisdom can be understood as a local idea that is wise, full of wisdom, good value, which is embedded and followed by members of the community. Local wisdom is formed as a cultural advantage of the local community as well as geographical conditions in the broadest sense. Wisdom and products of past cultures that should be constantly used as a handle on life. Although it is local in value, the value contained therein is considered very universal.

In Regional Regulation No. 3 of 2020 on Changes to Regional Regulation No. 16 of 2009 concerning Spatial Plan of Bali Province Year 2009-2029 has accommodated many local wisdom values that exist in indigenous Balinese communities. Some ofthe original P's in Regulation No. 3 of 2020 which in its content material accommodates the values of balinese lokalwisdom, among others: In the consideration of the philosophical foundation it has accommodated the protection of six sources of life in the universe, by including the philosophy of Namgun Sad Kerthi Loka Bali. This means that the foundation of this Regulation has philosophically included the value of loka wisdom that exists in Balinese society with oriented protection of natural and human resources in Bali. With the Philosophy of Sad Kerthi included in the consideration is expected in the level of implementation of this regulation there is a good synergy between humans and the universe, meaning that in building nature and humans in sad kerthi still worship Ida Shang Hyang widhi wasa in sad kahyangan to purify human self in order to continue to have commitment and consistency to realize the values of sad kertih in individual life and social life.

In Article 1 number 7 which contains the concept of tri hita karana philosophy that states that Tri Hita karana is a balinese philosophy of life that contains three elements that build balance and harmony of relationship between man with God, man with man, and man with his environment that becomes the source of welfare, peace, and happiness for human life. Then in the numbers 72, 73, 74 which contain related concepts bhisama, sad kerthi and tri mandala. Thus in the general provisions of the term the terms of local wisdom values have explained the concepts contained in the content material in the next articles. It aims to the same perception in the application of regional regulations in the future.

Then Article 3 of Regulation No. 3 of 2020 also includes the philosophy of Tri Hita karana and Sad Kerthi, 
aimed at realizing a quality, safe, comfortable, productive, self-depraved, competitive, environmentally friendly, and sustainable center for tourism, agriculture, and industry development imbued by Tri Hita Karana and sad kerthi fhilosophy.

Article 11 paragraph 2 letter $\mathrm{b}$ which states the development, utilization, and management of national protected areas and local wisdom-based protected areas in accordance with Sad Kerthi values, meaning that kerthi sad values are relevant to be used as guidelines in the development and utilization of regional management. Article 44 paragraph 10, 11.12 which there is also a term in people's lives in Bali as a distance or barrier in other designated areas such as apeneleng, apenyenker, apenimpug, this can be interpreted that the value of local wisdom in Balinese society is still recognized and trusted as a measure of distance determination in providing bats-limit.

Article 97 in also states that the concept of Space is based on the philosophy of Tri Hita Karana, Catus Patha, Tri Mandala integrated harmoniously with the local Customary Village palemahan system and the application of balinese building styles andenvironments, this means that there are classifications or levels in accordance with the designation of the area.

In Article 108 states the general arrangement of the Utilization of Space of the Sacred Place Area / temple of the universe or turggery area, divided into 3 (three) zones, including: 1. core zone, as the main zone of turggery area in accordance with the concept of maha wana; 2 . buffer zone, as a regional area of turdity in accordance with the concept of tapa wana; and 3. utilization zone, as a zone nista area of turdity in accordance with the concept of sri wana, this can be interpreted as a natural utilization area. This area is used for agricultural land and plantations. Even so, the area referred to as the productive zone must also remain natural. Sri Wana area is the main attraction of agricultural-based attractions. In this area will be emukana large rice field area known as perennial rice fields. With the utilization of sri wana area in accordance with the concept of Color Chess, this area remains a sustainable area as well as economically beneficial. Article 124 also indicates b. Space orientation refers to the concept of Catus Patha and Tri Mandala;b. Space orientation refers to the concept of Catus Patha and Tri Mandala,this is that there is value in the concept of Catus Patha

\subsubsection{Value of Local Wisdom Values in RTRW Regional Regulations Province of Bali.}

Could studied and analyzed that the value of local wisdom values can be seen rusteristically from several aspects including:

\section{Aspects of orientation:}

The value of local wisdom in the RTRW regional regulation is oriented to control, conservation of nature and the environment. (sad Kerthi, Tri Hita Karana, Tri mandala) So it can be concluded that the orientation of the local wisdom values that exist in spatial regulations is oriented conservation or maintenance.

\section{Aspects of Partisanship:}

From the level of law, namely spatial arrangement law No. 26 of 2007 that land space, sea, including in the earth, as part of the context of the environment that must be maintained, protected, and maintained the quality of its function. In a way of disnan. Utilizing and controlling its utilization, because space must be viewed as one inseparable unity with one another. Thus, it can be disbursed spatial arrangement is expected to realize a successful and useful spatial arrangement that can support sustainable environmental management of life, does not become a scattering of space utilization or exploitation of space, and does not cause degradation of space quality. So as to realize the purpose of article 33 paragraph 3 and Article 7 of the UUPR, the State organizes spatial arragements for the greatest prosperity of the people. Similarly, in spatial planning in Bali is aimed at realizing the people of Bali who are in harmony with the vis and mission of Bali development, namely"Nangun Sat Kerthi Loka Bali." Which contains the meaning of maintaining the sanctity and harmony of Bali's nature and its contents to realize a prosperous and happy Balinese krama life, while leading to the life of people and environment of Bali his people sovereign and independent from all aspects of both culture, politics and economy.

Basedon the description mentioned above, it can be said that the alignment of rung arrangements in favor of the community or krama by protecting nature and the environment from damage and pollution.

\section{Management Implementation}

Implementation of spatial arrangement, if listened to there is a detoxification of spatial arrangement in three groups, namely the center, province and regency / city. Politically, this is intended to mitigate the negative impact that may arise from the tug of war between the center and the Region. In the act of structuring the runag there are authorities given from the Center, province and district / City. Article 7 of uupr paragraph 2 states" the authority to implement theleveling of space to the Government and local government. Thus in the management of spatial arrangements can be said to adhere to the principle of decentralization in accordance with the Principle of Regional Autonomy.

\section{Human rights protection}

In Spatial Regulation there is the Concept of Tat Twam Asi" in the life of Hindu people in Bali. In the life of menyama braye actually crystallization / soul Tat Twam Asi has been reflected in the behavior of the community 
when socializing. dealing with problems between krame, placing themselves and others in speaking and behaving. There are crystals of Tat Twam Asi in the life of the customs of our society including:

1. Harmony, (mutual compassion, mutual compassion, mutual fostering, salunglung sabayantaka)

2. $\quad$ Alignment, (sagilik saguluk, briuk sapanggul);

3. Propriety, (paras-paros, ngawe sports wong len)

Thus the Spatial Regulation has accommodated the value of wisdom that respects human rights.

\section{People's Relationship with Natural Resources}

The relationship of people with natural resources can be seen in the principle of Tri Hita Karana where there are Pawongan and Palemahan that is the relationship between humans with their environment or the universe, in the arrangement of human space should not exploit space in such a way that it results in degradation of environmental or natural quality. The relationship between these natural people must be balanced. So is the principle of Tat twam Asi which is detrimental to damaging Nature merati damaging itself.

\section{Arrangements related to good governance.}

In the space management there is a principle of accountability that establishes accountability to the community. In Hinduism there is a local insecurity that we know as karma Phala The conception of Karma phala contains the value of causation because good deeds will always produce a good reward and vice versa. This conception is the foundation for self-control and an essential basis for moral development in many aspects of life, not least public service. ${ }^{\text {iv }}$

Even the teachings of Manava Seva-Madava Seva affirm that the service given to others is essentially also a service to God.

In Kakawin Nitisastra (Sargah XIII:9 Wirama Sardulavikridita) to said :

Ring wwang wastung iweh hinuttama, hane dehanya nityaneneb, sangkeng lobhanikangalap guna,

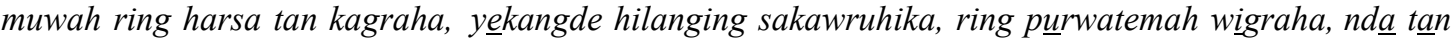
kagraha rakwa teki, wekasan sirnabalik nirguna.

The root of the greatest difficulty for man is hidden within himself. Leaders and power holders should limit desire because lust and denial of integrity cause people to behave contemptuously so as not to achieve the desired good.

Local wisdom of mukim indigenous law community in the arrangement of rice fields (blang), Mukim Lamteuba knows the customs of the luwah blangseason. According to custom, after finishing harvesting rice the blang area is left to be an open place, which takes place every year. The luwah blang season begins since the last farmer finished harvesting rice in his rice ields. Before all farmers finish harvesting rice applies"abstinence tot jeumpung"(forbidden toburn hay). The goal is to prevent the descent of buffalo herds(embassy)and cattle(leumo)from the field area (gle) or meurabe field to the blang area.

The practice of local wisdom of mukim indigenous peoples can be observed in the daily experience carried out by Mukim Lampanah, in the ecosystem area of Mount Seulawah, Aceh Besar Regency. Costums manages the forest with a ban on cutting wood in the customary uteun area (customary forest), such as in taleuk lhee, jungle goh ta'eun, and Teungku Keumuroh jungle.

Deer hunting time once a year. Logging in the forest for the construction of community houses is determined in size (diameter $30 \mathrm{~cm} /$ minimum age 3 years). Uptake of honey in one year in August, September and October (3 consecutive months). Outsiders who will take forest products must report to Commander Uteun or Imeum Mukim. Prohibition of cutting down trees where bees nest, opening gardens in customary protected forest areas. Prohibition of capturing livestock in mukim lampanah area without reporting to local breeder groups (specifically for livestock that come from other mukim but graze in lampanah area during the day)

Basically spatial arrangement is one form of government policy in the development of a region that includes 3 main processes; Space planning, space utilization and space utilization control. Its function is to create a safe, comfortable, productive, and sustainable regional space. The problem is that so strategic is the function of spatial arrangement, so it is not impossible if many people who want to intervene in the preparation of spatial arrangements given the opportunities given, the purpose and function of spatial planning.

In the Regional Spatial Regulations in Aceh, especially the Mukim Indigenous people. The essence of Mukim is the compatibility of man's relationship with God and his nature or the relationship of Lhee Sagoe. Reflection of the mindset of the indigenous law society that is magical-religious. Man is part of nature who must treat nature as it treats itself, as a trust from God to manage it. The mindset of participeren denken (humans are part of the natural system), if nature is damaged then his life will be threatened. First, mukim is a system of life and second, geographical, which integrates human elements, nature (flora \&fauna), imbued by the religion of Islam. The essence is a spatial arrangement system that reflects the local wisdom of aceh indigenous law communities that integrate economic, ecological, socio-cultural interests in a region as a system. In line with national development which is essentially a planned change, carried out systematically by integrating economic, ecological, socio-cultural interests to improve the welfare of the people. Second, RTRWA's Qanun legal politics do not accommodate sustainable spatial arrangements based on the local wisdom of mukim indigenous law 
communities, more oriented to economic interests by marginalizing the value system and interestsof mukim indigenous law communities with the politics ofignorance. The political construction of Qanun RTRWA existing (now) law substantially occurs inconsistencies and conflicts of norms with the above legislation, especially the law on the privileges and specificities of Aceh. Spatial planning with a rational comprehensive planning paradigm ignores the spatial layout of mukim indigenous law communities. Third, the reconstruction or construction of new political law Qanun sustainable spatial arrangements RTRWA based on the local wisdom of the mukim indigenous law community formulated by tracing the existing construction and construction of the political political correctness of Qanun sustainable spatial planning RTRWA based on the local wisdom of the mukim indigenous law community. Produce a new sustainable spatial law politics that accommodates and is based on the local wisdom of the Mukim indigenous law community in Aceh by adhering to the paradigm of legal pluralism and spatial planning that combines rational comprehensive planning with advocacy planning.

\subsubsection{Analysis of The Value of Local Wisdom In Spatial Regulations of Bali and Aceh Provinces}

The values of local wisdom in Bali in spatial arrangements have been accommodated in regional development, another case with Aceh the value of local wisdom has not been accommodated in the level of provincial regulations related to spatial planning this is due to the absence of political power owned by mukim people, research results in the residential area of Aceh Besar, Pidie Jaya and Aceh Besar found that generally the Mukim convey the same complaints where Mukim is not informed or involved in the preparation of RTRW in its territory. Mukim's authority is limited to the resolution of disputes arising between gampong residents in mukim territory. Mukim are the units of legal communities under sub-districts incorporated by several villages that have certain territorial heads led by mukim heads who are directly under the camat. Based on mukim custom is a gampong-gampong association therefore mukim act as coordinator in the relationship between gampong. In this case the mukim is in power in acting out, gampong is powerful in acting into the next mukim has the right to protect the rights and interests of the citizens gampong mukim is the superior of gampong and has the right to review certain decisions of gampong. Mukim people only coordinate with the camat. Mukim is directly located as an institution of customary government under the sub-district that oversees the combination of several camps in the local community structure in order to realize welfare and democratic life in the area of youth, preserving customs and customs, protecting the function of ecology and natural resources (SDA) in accordance with the awareness of the aspirations and needs of the people in the village who joined the structure of youth.

In contrast to the bali area, the indigenous people of Bali or indigenous villages institutionally have a bargaining position to the local government in terms of the establishment of regional regulations both at the district / city level and in the province. so that legal products at the regional level especially in Bali still accommodate the interests of indigenous communities based on the value of local wisdom values.

\subsection{Conclusion}

From the description of the discussion above it can be concluded that the values of local wisdom in Bali have characteristics when viewed from several aspects such as aspects of orientation, partisanship, respect for human rights, implementation of management and Good Governance found the value of local wisdom, among others: oriented conservation or maintenance, on aspects of partisanship of spatial arrangement in favor of the community or cramps by protecting nature and the environment from damage and pollution, in the aspect of human rights protection of spatial regulations have accommodated the value of wisdom that respects human rights, Tat Twam Asi.

The values of local wisdom in Bali in spatial arrangements have been accommodated in regional development, the values of local wisdom in mukim community when viewed from orientation, partisanship and protection in human rights in arranging the same space and territory as those in Bali, but there is in Aceh the value of local wisdom values have not been accommodated in the Provincial Regulation Level related to this spatial arrangement due to the absence of political power owned by oeh mas. Mukim society,

In Aceh, the concept of spatial arrangement based on local wisdom and sustainable through the role of Imeum Mukim. Mukim as a form of typical entity in Aceh has been recognized by the state and society, not only as the customary communal identity of acehnese people, but also as part of the regional governance and governance that has the authority to manage the wealth and sources of income mukim in accordance with the Qanun Mukim Government in each regency in Aceh. It can be concluded that the Aceh RTRW Regulation has not accommodated the local wisdom of structuring the space of the residential area and providing protection for mukim management areas from development activities and exploitative projects damaging and threatening people's livelihoods and potentially causing disasters. This is because the political power owned by the Mukim community has not been able to influence policies related to spatial arrangements, even though many values of local wisdom that can be used as guidelines in spatial arrangement in Aceh, related to respect, protection and fulfillment of rights to the community in providing welfare. 


\section{Daftar Bacaan}

iMuhammad Bakri, Right to Control Land by State,(Malang: UB Press, 2011), p.68.

ii Rachmad Safa'at. "IndigenousPeoples' environmental wisdom in Sustainable Resource Management: Case Analysis of Baduy Indigenous Peoples in the Context of Implementation of Daera $h$ Autonomy." In Rachmad Safa'at, et.al. State, Indigenous Peoples and Local Wisdom. (Malang: InTrans Publishing, 2008), 61.

iiiT. Nazaruddin, Sulaiman, Hasan Basri Malikussaleh University, Aceh, Indonesia, Law, Society and Local Wisdom as Social Capital In Aceh: Early Notes of SIASAT Journal of Social, Cultural and Political Studies, 4 (3) July 2019, 10-23

ivTitib, I Made, 1996, Veda: The Sacred Word of Life Prakts Guidelines,Paramita Publisher, Surabaya.

vT. Nazaruddin, Political Reconstruction of Sustainable Spatial Arrangement Law Based on Local Wisdom of Mukim Indigenous Law Community in Aceh,(Malang, Doctoral Study Program in Law, Faculty of Law, Universitas Brawijaya, 2017), p. 129

\section{Legislation}

Law No. 26 of 2007 concerning Spatial Arrangement

Bali Provincial Regulation No. 16 of 2009 concerning RTRW of Bali Province 2009-2029

Bali Provincial Regulation No. 3 of 2020 on Changes to Bali Provincial Regulation No. 16 of 2009 on RTRW of Bali Province 2009-2029 